日臨外会誌 $78 （ 9), 2104-2111,2017$

症例

悪性リンパ腫の精査を機に発見された直腸悪性黒色腫の 1 例

仙台市立病院外科

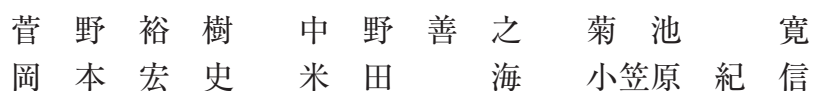

症例は68歳, 女性. 中枢神経病変を伴う悪性リンパ腫の診断となり, FDG/PETを撮 影し左側頭葉, 肝門部, 傍大動脈および下部直腸にFDGの高集積を認めた。 下部消化 管内視鏡検査では下部直腸から肛門管に黒色隆起性病変を認め, 生検で悪性黒色腫の診 断となった，悪性リンパ腫の進行による意識障害が急速に出現したため, 悪性リンパ腫 に対する治療を優先し, 化学放射線療法を施行する方針とした. R-MPV療法 (rituximab, methotrexate, procarbazine, vincristine）を開始した結果，意識障害は消失し，FDG/ PETでは直腸病変以外は partial response：PRであった. 悪性リンパ腫が奏効状態と なり悪性黑色腫も治療適応と考え, 腹腔鏡補助下直腸切断術を施行した. 術後15力月が 経過した現在，直腸悪性黒色腫の再発はない.

索引用語：直腸悪性黒色腫, 悪性リンパ腫

\section{はじめに}

直腸悪性黒色腫は稀な疾患である。今回われわれは 悪性リンパ腫の精查を機に発見された直腸悪性黒色腫 の 1 例を経験したので報告する.

\section{症例}

患者：68歳, 女性.

主訴 : 視力低下.

既往歴: 子宮筋腫 (40代), サルコイドーシス (57歳), 高血圧 (66歳), 白内障 (68歳, 手術), 糖尿病 (68歳).

現病歴：2015年 4 月に視力低下を自覚し近医眼科を 受診し, サルコイドーシス性ぶどう膜炎の診断で内服 加療が開始となった．改善傾向を認めないため2015年 7 月に前医に紹介となり, 硝子体生検を施行した結果, びまん性大細胞性悪性リンパ腫の診断となった。 FDG/PETにて, 左側頭葉, 肝門部, 傍大動脈および 下部直腸にFDGの高集積を認めた。下部消化管内視 鏡検査では下部直腸から肛門管にかけて黒色の 0 - I $\mathrm{sp}$ 型腫瘍を認めた．生検で直腸悪性黒色腫の診断で あった，その後，悪性リンパ腫の進行による意識障害 が急速に出現したため, 悪性リンパ腫の治療を優先す

2017年 4 月 21 日受付 2017 年 7 月 1 日採用

〈所属施設住所〉

テ982-8502 仙台市太白区あすと長町 $1-1-1$
ることとなり，2015年 9 月に化学放射線療法を施行す る方針とした。

R-MPV療法を計 5 コースおよび全脳照射 $23.4 \mathrm{~Gy}$ +両側眼窩照射7.2 Gy 施行した結果, 中枢神経症状 は完全に消失し, 画像評価では直腸病変以外はPRの 判定となった. 直腸悪性黒色腫も治療適応と判断し, 2015年12月に手術目的に当科紹介となった.

入院時現症 : 身長 $152.5 \mathrm{~cm}$, 体重 $47.0 \mathrm{~kg}$. 腹部は平坦, 軟で腫瘤を触知しなかった，両側鼠径部をはじめ，体 表リンパ節を触知しなかった．直腸診では 3 時の方向 に約 $30 \mathrm{~mm}$ 大の弾性軟の隆起性腫瘤を触知した.

血液生化学検査 : $\mathrm{Hb} 9.1 \mathrm{~g} / \mathrm{dL}$, Plt $14.0 \times 10^{4} / \mu \mathrm{L}$ と 化学療法の影響と考えられる貧血, 血小板低下を認め た。 その他異常所見を認めなかった。化学療法開始前 はLDH $410 \mathrm{U} / \mathrm{L}, \quad s I L-2 R$ 1,730 U/mLと高值を認め たが，術前にはLDHは175 U/Lと正常值に, sIL-2R は775 U/mLと軽度高值であるものの低下していた。

下部消化管内視鏡検査 : 3 時の方向に $30 \mathrm{~mm}$ 大の 0 - I sp型黒色腫瘍を認めた (Fig. 1a). 同部位より生 検を行った結果, 悪性黒色腫であった. R-MPV 療法 5 コース施行後の再検では腫瘍の大きさは $26 \mathrm{~mm}$ 大で やや縮小していた（Fig. 1b).

FDG/PET : 治療開始前の FDG/PET では左側頭葉, 肝門部, 傍大動脈および下部直腸にFDGの高集積を 

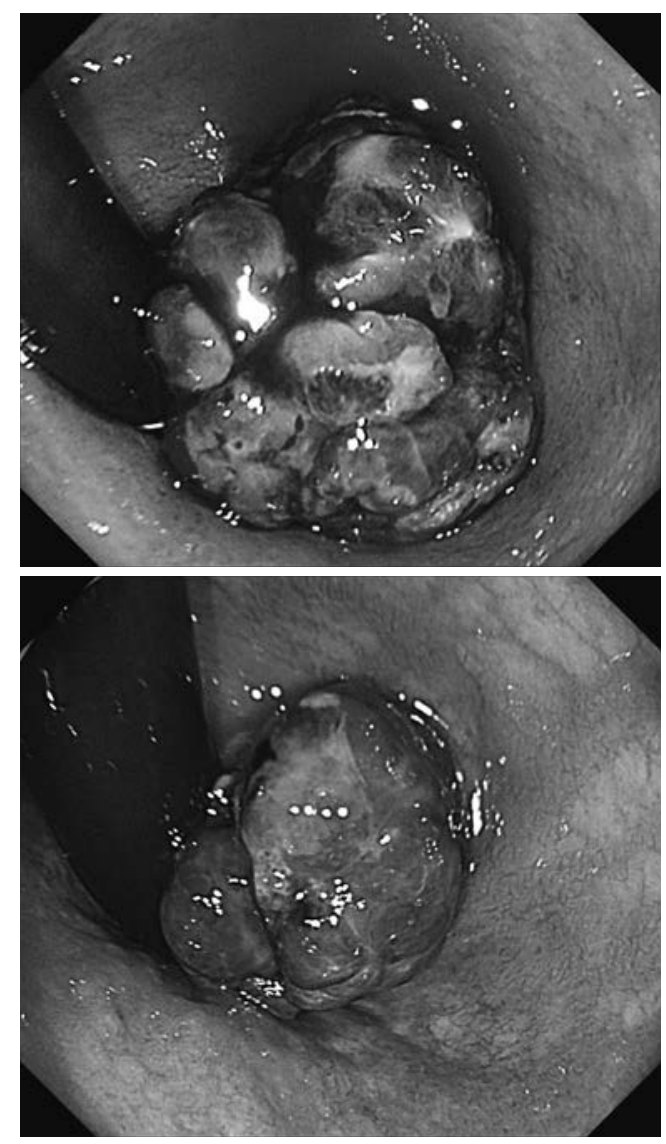

Fig. 1 下部消化管内視鏡所見 $(\mathrm{a}$ : 化学療法施行前, b : 化学療法施行後)：下部直腸から肛門管にかけ て $30 \mathrm{~mm}$ 大の黒色隆起性腫瘍を認めた。化学療法 施行後は $26 \mathrm{~mm}$ 大に縮小し, 黒色調が明瞭化して いた。

認めた（Fig. 2a， b， c)．化学療法施行後のFDG／ PETでは下部直腸のみに集積を認め, 他部位の集積 は消失していた（Fig. 2d，e，f）。

骨盤部MRI：直腸左側後壁寄りに $\mathrm{T} 1$ 強調画像で高 信号, T2 強調画像で低信号の隆起性腫瘤を認めた. 壁外進展や腸管傍リンパ節，側方リンパ節，鼠径リン パ節転移は認めなかった（Fig. 3a， b).

$\mathrm{CT}$ ：遠隔転移掞よびリンパ節転移を示唆する所見 を認めなかった。

以上より直腸悪性黒色腫, cT $1 b, c N 0, c \mathrm{M} 0, \mathrm{cStage}$ I の診断で化学療法開始から126日後に手術を施行し た. 化学療法終了後からは55日後であった.

手術所見 : 2016年 1 月初旬に腹腔鏡補助下直腸切断
術，D2 郭清を施行した。リンパ節転移，肝転移，腹 膜播種は認められなかった。

切除標本肉眼所見: 下部直腸から肛門管にかけて $26 \mathrm{~mm} \times 23 \mathrm{~mm}$ 大の黒色の有荎性腫瘍を認めた（Fig. 4).

病理組織学的所見 : RbP, 0 - I sp, $26 \times 23 \mathrm{~mm}, \mathrm{pT} 1 \mathrm{~b}$, ly1, v0, pN0 $(0 / 10)$, pPM0, pDM0, pRM0, 悪 性黒色腫, pStage I .

随所にびらんを形成しており，大型多角球，腫大し た核小体と淡好酸性の細胞質を有する異形細胞がびま ん性に増殖浸潤していた。異形細胞は胞体内に豊富な メラニン顆粒を含有していた．免疫染色では HMB45 陽性，MelanA 陽性であった（Fig. 5).

術後経過: 術後経過に問題なく第26病日に退院した. 術後45日目のFDG/PETで縦隔リンパ節にFDGの高 集積を認め, 悪性リンパ腫の再燃と考え, 化学療法を 施行中であるが, 術後15力月が経過した現在まで直腸 悪性黒色腫の再発はない.

\section{考察}

直腸悪性黒色腫は稀な疾患であり，その頻度は直腸 肛門部悪性腫瘍の $0.05 \sim 4.6 \%$, 全悪性黒色腫の 0.4 $1.6 \%$ とされる. 好発年齢は 50 ～70代 (平均年齢68.5歳) で，女性が男性の約1.7倍多いとされる。予後は極め て不良で， 5 年生存率は 6 〜 22\%とされる122).

医学中央雑誌で1997年から2016年の期間で「直腸肛 門部悪性黒色腫」または「直腸悪性黒色腫」をキーワ ードとして検索（会議録を除く）したところ，87編 100症例の報告を認めた。これに自験例を加えた101症 例に関して検討を行った。平均年齢は68歳，男女比は 男: 女= $1: 1.5$ であった。主訴は出血が多く, 腫瘤触 知, 疼痛が次いだ。腫瘤の大きさは $3 \sim 110 \mathrm{~mm}$ と幅 広く，10例は複数個の腫瘤を有していた１9例が低〜 無色素性であった。肉眼形態は大部分が 0 - I 型およ び 1 型の隆起性腫瘤であったが， 2 型および 5 型腫瘤 を10例認めた。術式は直腸切断術が75例, 局所切除が 17例施行されていた，壁深達度は $\mathrm{m}$ 癌が 8 例あり, いずれも 0 であった. $\mathrm{sm}$ 癌は33例あり，その内 14 例 が $\mathrm{n}(+)$ であった. 10 例が 5 年以上の無再発生存期間 を有しており，それらに共通した項目は 0 - I 型また は 1 型の隆起性腫瘤であることのみであった。逆に, 2 型または 5 型腫瘤の 10 例中 8 例が診断時遠隔転移を 有しているか, 数力月で再発をきたしおり予後不良で あった（Table 1)

医学中央雑誌で「直腸悪性黒色腫」「悪性リンパ腫」 

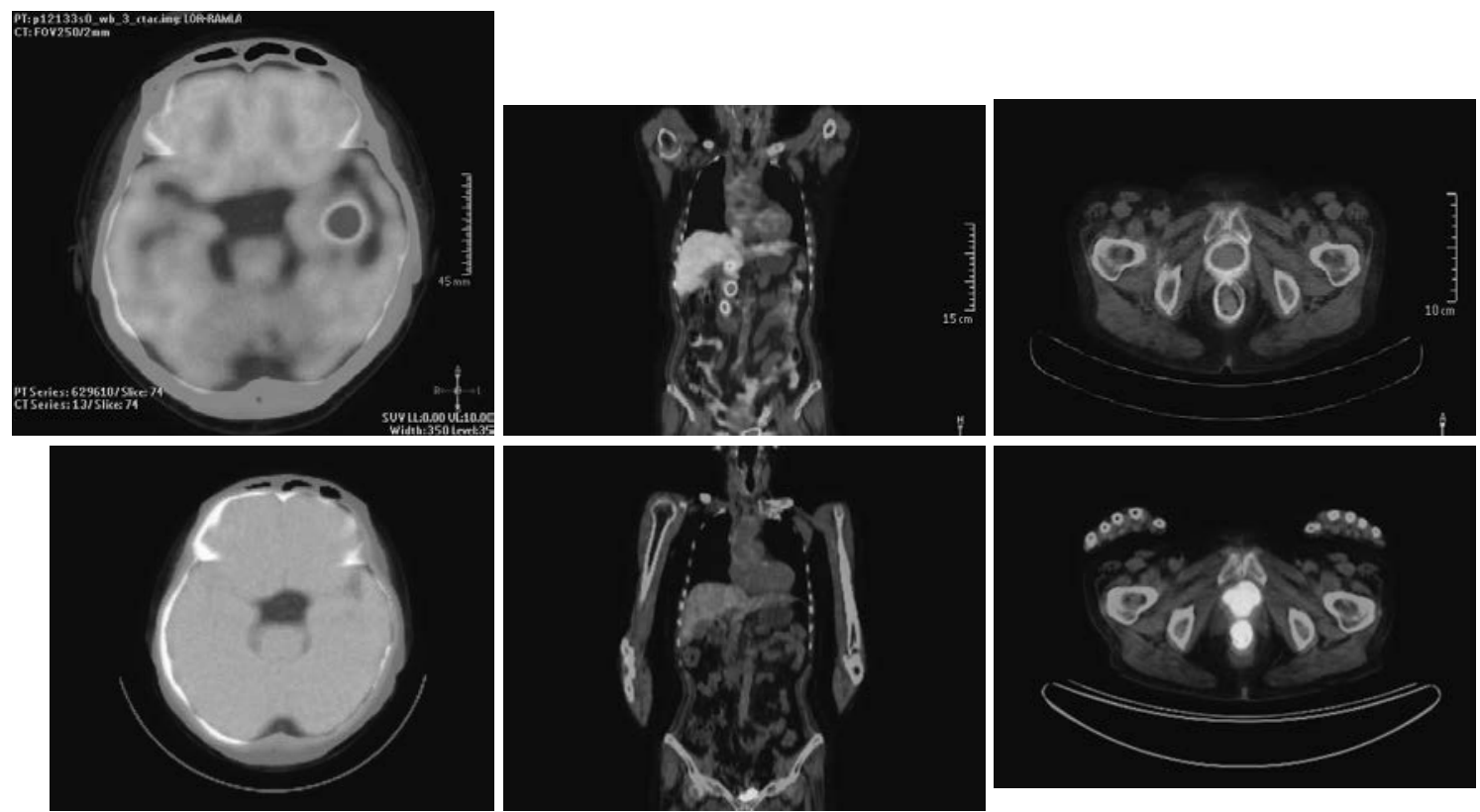

Fig. 2 FDG/PET (a, b, c : 化学療法施行前/d, e, f : 化学療法施行後) : 左側頭葉, 肝門部, 傍大動脈および直腸に FDGの高集積を認めたが, 化学療法施行後では左側頭葉・肝門部・傍大動脈の集積は消失し, 直腸のみにFDGの集積 が残存していた.

\begin{tabular}{l|l|l}
$\mathrm{a}$ & $\mathrm{b}$ & $\mathrm{c}$ \\
\hline $\mathrm{d}$ & $\mathrm{e}$ & $\mathrm{f}$
\end{tabular}

を, PubMedで「anorectal malignant melanoma」 $\lceil$ malignant lymphoma」をキーワードとして検索（会 議録を除く）したが，悪性リンパ腫と直腸悪性黒色腫 を併発した報告例は認めなかった。「悪性リンパ腫」「重 複癌」をキーワードとして検索すると多数の報告例を 認め，悪性リンパ腫に併存する悪性腫瘍としては胃癌 が最も多く $(38 \%)$, それに大腸癌を加えると消化器 癌が $53 \%$ を占めるとの報告を認めた ${ }^{3)}$. 自験例では, その特徴的な臨床所見から診断は容易ではあったが, リンパ腫と固形癌の転移性病変との鑑別に難渋する時 には積極的に組織診断を行うべきであると考えられ た。

診断は生検でメラニン色素を多く含む腫瘍細胞を認 めることによって主になされるが，10～30\%では無色 素性のため未分化癌や低分化型腺癌と誤診されること があり，注意を要する。その場合にはS-100蛋白， HMB-45, MelanAなどの免疫染色が有用である4)5). 画像所見としてMRIではメラニンが常磁性であるた めT1 強調画像で高信号, T2 強調画像で低信号と高 信号が混在した特異的な所見を示し，造影すると辺縁 が強く濃染することが報告されている ${ }^{6)}$.
治療は外科的切除が基本とされる. 原ら ${ }^{7)}$ は長期生 存の条件として(1)腫瘍最大径が $5 \mathrm{~cm}$ 以内であること, (2)壁深達度が mp 以内であること, (3)リンパ節転移の 有無にかかわらず広範なリンパ節郭清を伴う腹会陰式 直腸切断術が行われたこと，の3 点を挙げており，コ ンセンサスは得られていないものの本邦では直腸切断 術が選択されることが多い. 欧米では局所切除と直腸 切断術との間で予後に差がなかったとの報告8)9) があ り，局所切除が好まれる傾向がある．局所切除を選択 する条件として中島ら ${ }^{10)}$ は(1)隆起・有茎性病変で潰瘍 形成を認めない, (2)深達度が sm以浅, (3)局所切除に て完全切除が可能，の 3 点を挙げているが, 深達度 smであってもリンパ節転移を認めた例11) 13)や, skip lesion や表層拡大型進展を認めた例14) 16) もあり, その 選択は慎重に行うべきと考えられる．Table 1におい ても sm癌33例中14例にリンパ節転移を認めており, 根治切除を目指すうえでは深達度 $\mathrm{sm}$ の症例に対して は局所切除は適応外と考えられる.

化学療法はDTIC (dacarbazine) を中心とした多 剂併用療法が行われている。なかでも DTIC, ACNU (nimustine hydrochloride), VCR (vincristine sul- 


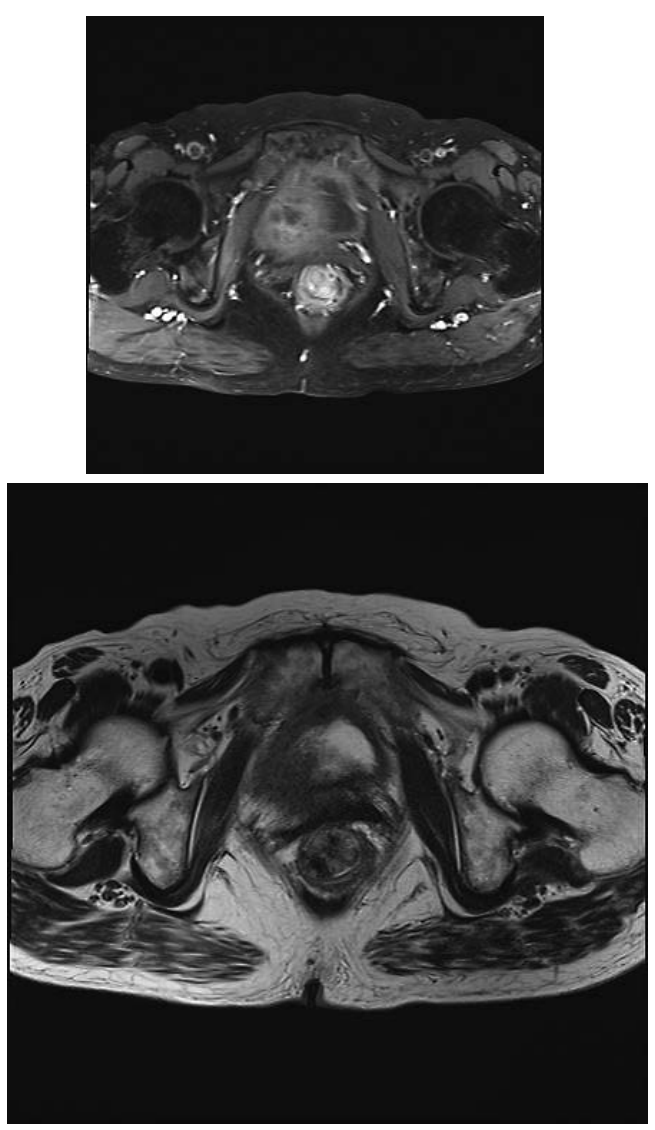

Fig. 3 骨盤部MRI（ $\mathrm{a}$ ：T1 強調画像, b：T2 強 調画像）：直腸左側後壁寄りに $\mathrm{T} 1$ 強調画像で高信 号, T2 強調画像で低信号の腫瘤を認めた。 $\frac{\mathrm{a}}{\mathrm{b}}$

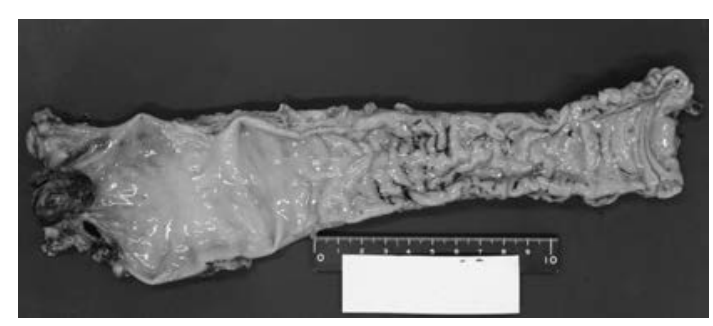

Fig. 4 切除標本肉眼所見 : 下部直腸から肛門管にかけ て26 mm × $23 \mathrm{~mm}$ の黑色隆起性腫瘍を認めた.

fate）の 3 剂併用であるDAV療法が広く用いられて おり, これにインターフェロン $\beta$ の局所投与を合わせた DAV-feronが有効との報告がある12). 他にはDACTam療法 (dacarbazine, nimustine hydrochloride, cisplatin, tamoxifen), CDV 療法 (cisplatin, dacarbazine,
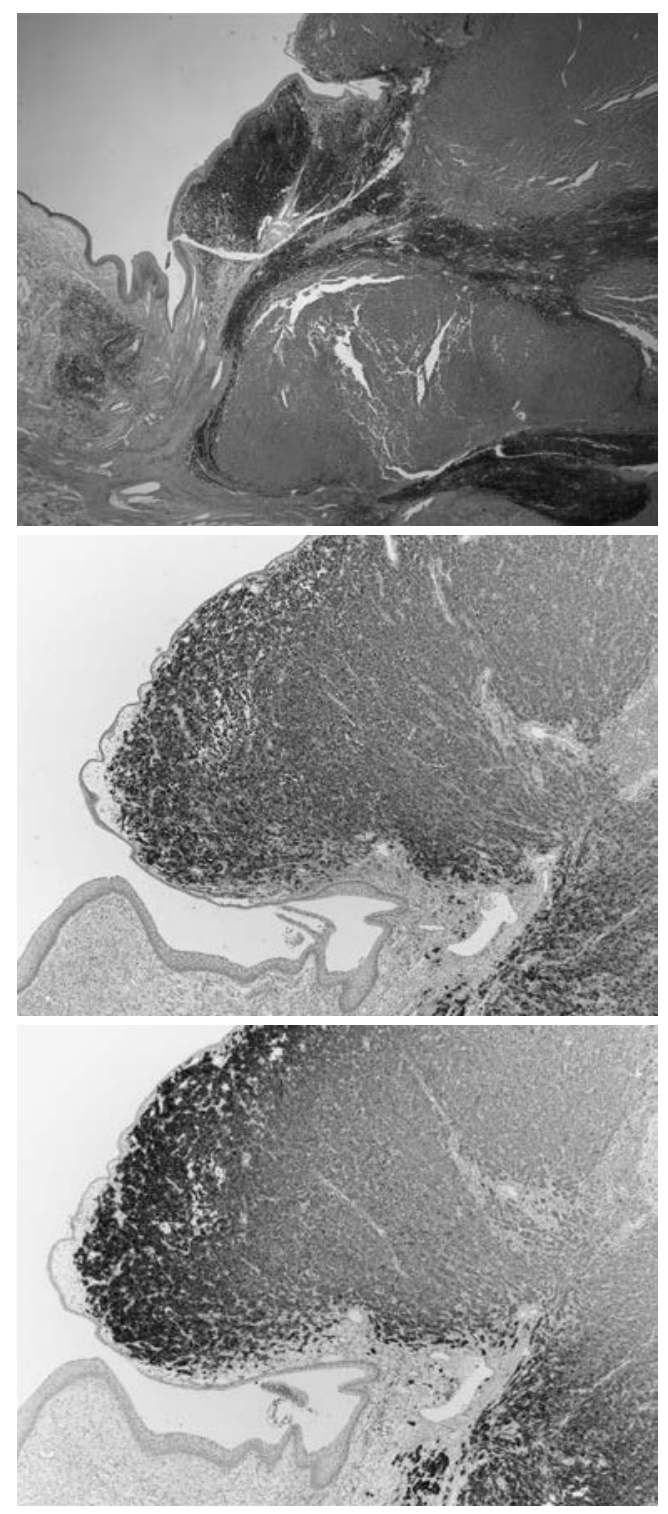

Fig. 5 病理組織学的所見 ( $\mathbf{a}:$ H.E. 染色, b : HMB-45, c : Melan-A)

胞体内に豊富なメラニン顆粒を有する異型細胞が びまん性に増殖浸潤していた. HMB-45, Melan-A 陽性であり悪性黒色腫の診断となった。

$$
\frac{\mathrm{a}}{\mathrm{b}}
$$

vindesine), CP療法 (carboplatin, paclitaxel) や paclitaxel 単剂療法が有効であったとの報告もある17) 20).

近年, 切除不能皮膚悪性黒色腫に対してヒト型抗ヒ ト programmed cell death-1 (PD-1) (CD279) モノク 
Table 1 直腸（肘門部）悪性黒色腫本邦報告101例（1997～2016年）

\begin{tabular}{|c|c|c|c|c|c|c|c|c|c|c|c|c|c|c|}
\hline 症例 & 著者 & 報告年 & 年齢/珄別 & 症状 & 腫瘍径 & 色調 & 肉眼形態 & 術前誜斷 & 治療 & 樑達度 & 服管侵襲 & リンパ節 & 補助化学療法 & 無再発生存期間 \\
\hline 1 & 高森战 & 1997年 & 47歲/男 & 下血 & $50 \times 25 \mathrm{~mm}$ & 記載なし & 1型 & 記載なし & 直腸切断術 & $\mathrm{sm}$ & ly2, v1 & n0 & DAV & 1年2力月 \\
\hline 2 & 佐藤ら & 1997年 & 61歳/女 & 下血, 肛門部隀瘤 & $30 \mathrm{~mm}$ & 黑色班 & 0 - Isp & 悪性黑色氃 & $\begin{array}{l}\text { 未施行 } \\
\end{array}$ & - & - & - & - & 診断時遠陑転移+ \\
\hline 3 & 篠田乩 & 1998年 & 69歲/男 & 肛門部腫瘦 & $50 \times 35 \mathrm{~mm}$ & 周囲と同色調 & SM T & 悪性黑色腫 & 直腸切断術 & a & 記載なし & $\mathrm{n} 0$ & DAV-feron & 7カ月以上 \\
\hline 4 & 遠藤ら & 1998年 & 52歲/女 & 排便時出血 & $37 \times 27 \mathrm{~mm}$ & 赩, 黑褐色 & 0 -Is & 肛門腄瘤 & 局所切除 & $\mathrm{sm}$ & 記载なし & - & DAV & 1 年 6 力月以上 \\
\hline 5 & 真杖 & 1998年 & 61歲/男 & 排便時出血 & $32 \times 30 \times 20 \mathrm{~mm}$ & 淡褐色 & $0-I p$ & 悪性黑色腫 & 直腸切断術 & 記載なし & 記载なし & $\mathrm{n}^{+}$ & 未施行 & 6力月 \\
\hline 6 & Ojima 5 & 1999年 & 68歲/女 & 下血 & $17 \times 15 \times 13 \mathrm{~mm}$ & 一部黑色 & 0 - Isp & 悪性黑色腫 & 直腸切断術 & $\mathrm{sm}$ & 記载なし & $\mathrm{n} 0$ & 未施行 & 18力月以上 \\
\hline 7 & 鉿木5 & 1999年 & 57歲/女 & 排便時出血 & $25 \times 22 \mathrm{~mm}$ & 赤褐色 & 0 -Is & 低分化腺癌 & 局所切除 $\rightarrow$ 直晹切断術 & $\mathrm{mp}$ & 記載なし & $\mathrm{n} 2$ & DAV & 5カ月 \\
\hline 8 & & " & 46歲/女 & 股門部痛 & $60 \times 60 \times 50 \mathrm{~mm}$ & 一部黑色 & 1型 & 悪性黑色腫 & 直腸切断術 & a & ly3, v0 & n2 & - & 手術時遠陑転移+ \\
\hline 9 & 村山ら & 1999年 & 67歲/男 & 排便後出血，腄瘤脱出 & $27 \times 35 \times 15 \mathrm{~mm}$ & 青黑色 & 0 - Isp & 悪性黑色腫 & 直腸切断術 & $\mathrm{mp}$ & ly0, v0 & $\mathrm{n} 0$ & 未施行 & 1 年 2 力月以上 \\
\hline 10 & 若林5 & 1999年 & 60歲/女 & 血便 & $50 \times 40 \mathrm{~mm}$ & 灰白色 & 2型 & 診断つかず & 局所切除 & \begin{tabular}{|l|} 
記載なし \\
\end{tabular} & 記載なし & 記载なし & 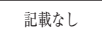 & 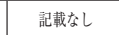 \\
\hline 11 & 平尾 5 & 1999年 & 65歳/男 & 肛門部痛 & $35 \times 30 \mathrm{~mm}, 17 \times 11 \mathrm{~mm}$ & 黒色 & $0-I p$ & 悪性黑色腫 & 直腸切断術 & $\mathrm{sm}$ & v0, lyl & $\mathrm{nl}$ & DAV & 3力月以上 \\
\hline 12 & 渡边ら & 2000 年 & 64歲/男 & 鼠径部腫㿇 & 記載なし & 黒色 & 2型 & 悪性黑色腫 & 人工肛門造設 & - & - & - & - & 診断時遠隔転移+ \\
\hline 13 & 照屋战 & 2001年 & 68歳/女 & 排便時肛門痛 & $30 \times 35 \mathrm{~mm}$ & 黒色 & 1型 & 悪性黑色腫 & 直腸切断術 & a & lyl, v0 & $\mathrm{nl}$ & DAV & 記載なし \\
\hline 14 & & " & 69歲/女 & 排便時出血 & $3 \sim 25 \mathrm{~mm}$ & 黒色 & $0-I p$ & 悪性黑色腫 & 直腸切断術 & $\mathrm{mp}$ & 記載なし & $\mathrm{n} 2$ & 未施行 & 1 年 \\
\hline 15 & 西科放 & 2001年 & 76歳/男 & 肧門出血 & $10 \times 8 \times 8 \mathrm{~mm}$ & 灰白色 & $0-\mathrm{Ip}$ & 悪性黑色腫 & 局所切除 & $\mathrm{m}$ & - & - & 未施行 & 8 年以上 \\
\hline 16 & & " & 72歳/女 & 排便時出血 & $10 \mathrm{~mm}, 25 \mathrm{~mm}$ & 黑褐色 & 0 - Isp & 悪性黑色腫 & 直腸切断術 & $\mathrm{sm}$ & $\mathrm{v} 0$, ly0 & $\mathrm{n} 0$ & 未施行 & 4 年 1 力月以上 \\
\hline 17 & 田村 & 2001年 & 76歳/男 & 血便 & $62 \times 48 \times 15 \mathrm{~mm}$ & 暗褐色 & 1型 & 悪性黑色腫 & 直腸切断術 & $\mathrm{mp}$ & 記载なし & $\mathrm{n} 2$ & 記载なし & 記載なし \\
\hline 18 & 小田ら & 2001年 & 80歳/女 & 肛門出血, 脱肛 & $39 \times 32 \mathrm{~mm}, 37 \times 17 \mathrm{~mm}$ & 暗赤色 & 0 -Is & 悪性黑色腫 & 直腸切断術 & a & lyl, vl & $\mathrm{n} 0$ & 未施行 & 8カ月 \\
\hline 19 & 板野ら & 2002年 & 67歳/男 & 血便 & $15 \times 12 \times 8 \mathrm{~mm}$ & 一部黑色 & 0 - Isp & 悪性黑色腫 & 直晹切断術 & $\mathrm{m}$ & ly0, v0 & $\mathrm{n} 0$ & 未施行 & 3 力月以上 \\
\hline 20 & 山本ら & 2002年 & 80歳/男 & 下血 & $50 \mathrm{~mm}$ & 黑褐色 & $0-I p$ & 悪性黑色腯 & 局所切除 & 記載なし & 記载なし & 記載なし & 未施行 & 記載なし \\
\hline 21 & Fukui 5 & 2002年 & 54歳/女 & 記載なし & $6 \times 5 \mathrm{~mm}$ & 黒班 & $0-\mathrm{Ip}$ & 悪性黑色腫 & 直晹切断術 & 記載なし & 記載なし & 記載なし & DAV-feron & 6 年以上 \\
\hline 22 & & " & 74歳/女 & 下血 & $110 \times 90 \times 65 \mathrm{~mm}$ & 黒色 & 1型 & 悪性黑色腪 & 直晹切断術 & $\mathrm{mp}$ & 記載なし & $\mathrm{n}^{+}$ & DAV & 記載なし \\
\hline 23 & & " & 71歳/女 & 腄瘤蝕知 & $65 \times 55 \mathrm{~mm}$ & 黒色 & 1型 & 悪性黑色腫 & 直晹切断術 & $\mathrm{mp}$ & 記載なし & $\mathrm{n}^{+}$ & DAV-feron & 記載なし \\
\hline 24 & & " & 75歳/男 & 下血 & $90 \times 70 \mathrm{~mm}$ & 黑色 & 1型 & 悪性黑色腫 & 直腸切断術 & ai & 記载なし & $\mathrm{n}^{+}$ & DAV-feron & 記載なし \\
\hline 25 & 伊澤ら & 2002年 & 68歳/男 & 記载なし & 記載なし & 記載なし & 1型 & 墨性黑色腫 & 直晹切断術 & $\mathrm{sm}$ & $\mathrm{v} 0$, $\operatorname{ly} 0$ & $\mathrm{nl}$ & DAV & 1 年11力月 \\
\hline 26 & 太田ら & 2002年 & 64歳/女 & 便秘 & $70 \times 65 \mathrm{~mm}$ & 黒色 & 1型 & 悪性黒色腫 & 直晹切断術 & a & $\mathrm{v} 2$ & n2 & - & 䛦铒時遠隔転移 + \\
\hline 27 & 秦ら & 2003年 & 65歲/女 & 排便時出血 & $30 \times 17 \mathrm{~mm}$ & 黑褐色 & 1型 & 記载なし & 直腸切断術 & $\mathrm{sm}$ & lyl, v1 & $\mathrm{nl}$ & 未施行 & 1 年 7 力月上 \\
\hline 28 & 宍戸ら & 2003年 & 66歲/女 & skin tag增大 & $14 \mathrm{~mm}$ & 黑色 & 0 - Isp & 悪性黑色腫 & 局所切除 & $\mathrm{m}$ & 記載なし & - & DAV-feron & 9 力月以上 \\
\hline 29 & 大澤ら & 2003年 & 64歲/男 & 肛門部腫瘤 & $40 \times 35 \times 25 \mathrm{~mm}$ & 黑色 & 1型 & 悪性黑色腫 & 局所切除 & $\mathrm{mp}$ & lyl, v1 & - & - & 䛦断時遗陑転移 + \\
\hline 30 & Sato 5 & 2003年 & 84歲/女 & 下血, 便秘 & $90 \times 75 \mathrm{~mm}$ & 灰褐色 & 2型 & 悪性黑色腫 & 直腸切断術 & a & ly0, v2 & $\mathrm{n} 2$ & なし & 3力月 \\
\hline 31 & 後藤ら & 2003年 & 73歲/男 & 下血, 肛門部隀瘫 & $40 \mathrm{~mm}$ & 一部黑色調 & $0-I p$ & 悪性黑色腫 & 直腸切断術 & $\mathrm{mp}$ & lyt & $\mathrm{n}^{+}$ & 記載なし & 記載なし \\
\hline 32 & 岸本ら & 2004年 & 73歲/女 & なし (TCSにて偶然) & $30 \times 25 \times 25 \mathrm{~mm}$ & 黒色 & 5型 & 悪性黑色腫 & 局所切除 $\rightarrow$ 直晹切断術 & 記載なし & 記載なし & $\mathrm{n}^{+}$ & $\mathrm{CDV}$ & 2力月 \\
\hline 33 & 柴田 & 2004年 & 67歲/男 & 肚門出血 & $50 \times 30 \mathrm{~mm}$ & 白色 & 記载なし & 横紋筋肉腫 & 局所切除 $\rightarrow$ 直腸切断術 & 記載なし & 記載なし & 記載なし & 未施行 & 断端陽性 \\
\hline 34 & 櫻井战 & 2004年 & 53歲/男 & 下血 & $20 \times 10 \mathrm{~mm}$ & 周囲と同色調 & 0 - Isp & 悪性黑色腫 & 局所切除 & $\mathrm{mp}$ & 記载なし & - & $\mathrm{CDV}$ & 1 年6力月 \\
\hline 35 & 土田ら & 2004年 & 65歲/女 & 下血 & $10 \mathrm{~mm}, 5 \mathrm{~mm}$ & 黑色 & $0-\mathrm{Ip}$ & 肛門ポリーブ & polypectomy $\rightarrow$ 局所切除 & $\mathrm{sm}$ & 記載なし & 記載なし & DAV-feron & 6 年以上 \\
\hline 36 & 川田ら & 2004年 & 53歳/女 & 排便時出血，肛門痛 & $80 \times 80 \mathrm{~mm}$ & 黑色 & 記載なし & 悪性黑色腫 & 直腸切断術 & 記載なし & ly2, v1 & n2 & 未施行 & 手術時遗隌転移 + \\
\hline 37 & 長欲川ら & 2005年 & 73歳/女 & 下血, 肛門痛 & $55 \times 25 \mathrm{~mm}, 16 \times 7 \mathrm{~mm}$ & 一部黑色 & 1型 & 悪性黑色腫 & 直腸切断術 & $\mathrm{mp}$ & ly0, v0 & $\mathrm{n} 0$ & 未施行 & 7 年 3 力月以上 \\
\hline 38 & 外山ら & 2005 年 & 59歳/男 & 検診異常 & $32 \times 30 \mathrm{~mm}$ & 暗赤色 & 0 - Isp & 覀性黑色随 & 直腸切断術 & $\mathrm{sm}$ & $\mathrm{ly}(+), \quad \mathrm{V}(+)$ & $\mathrm{n} 0$ & $\mathrm{CDV}$ & 6 年以上 \\
\hline 39 & 板野占 & 2006年 & 63歳/男 & 肛門痛，下血，脱肛 & $33 \times 24 \mathrm{~mm}$ & 一部黑色 & 0 - Isp & 悪性黑色腫 & 局所切除 & 記載なし & 記载なし & - & 未施行 & 2 年以上 \\
\hline 40 & 高木ら & 2006年 & 70歳/女 & 軟便 & $20 \mathrm{~mm}$ & 一部黒色調 & $0-I p$ & 記載なし & 局所切除 $\rightarrow$ 直晹切断術 & $\mathrm{mp}$ & 記载なし & $\mathrm{nl}$ & DAV & 4 力月以上 \\
\hline 41 & 高木ら & 2006年 & 73歳/男 & 肛門部痛 & $55 \times 45 \mathrm{~mm}$ & 黑色 & 1型 & 墨性黑色腫 & 直腸切断術 & a & ly0, v1-2 & $\mathrm{n}(+)$ & DAV-feron & 記載なし \\
\hline 42 & 清水的 & 2006年 & 77歳/男 & 下血 & $35 \times 35 \mathrm{~mm}$ & 黑色 & 2型 & 悪性黑色腫 & 直腸切断術 & $\mathrm{mp}$ & ly3, v1 & $\mathrm{nl}$ & なし & 䛦钒時遗隔䎐移 + \\
\hline 43 & 平沼 & 2006 年 & 89歳/女 & 排便時出血 & $22 \times 18 \mathrm{~mm}$ & 黑色 & 記載なし & 悪性黑色腫 & 直腸切断術 & $\mathrm{m}$ & ly0, v0 & n0 & 未施行 & 1 年以上 \\
\hline 44 & 小倉ら & 2007 年 & 69歳/女 & 下血 & $10 \mathrm{~mm}$ & 黑色調 & $0-$ Isp & 悪性黑色腫 & 局所切除一直腸切断術 & $\mathrm{sm}$ & ly0, v0 & 記載な⿰ & 未施行 & 1年9カ月 \\
\hline 45 & 赫ら & 2007 年 & 79歳/女 & 肛門出血 & $3 \mathrm{~mm}, 5 \mathrm{~mm}, 8 \mathrm{~mm}$ & 白色 & 0 - Isp & 肛門ポリープ & EMR & 記載なし & 記載なし & $\mathrm{n} 0$ & 未施行 & 9力月 \\
\hline 46 & 北川ら & 2007 年 & 77歳/女 & 排便時出血，腫瘤脱出 & $40 \mathrm{~mm}$ & 黑色 & 0 - Isp & 墨性黑色腫 & 直腸切斷術 & $\mathrm{m}$ & 記載なし & $\mathrm{n} 0$ & 未施行 & 13 力月以上 \\
\hline 47 & Seya 5 & 2007 年 & 40歳/男 & 下血 & 記載なし & 記載なし & 記载なし & 神経内分䎵癌 & 直腸切断術 & 記載なし & 記載なし & 記載なし & 未施行 & 䛦斷時遗滑転移 + \\
\hline 48 & 手塚ら & 2007 年 & 61歳/男 & 肛門部出血 & $30 \times 2 \mathrm{~mm}$ & 暗赤黑色 & 1型 & 悪性黑色腫 & 直晹切断術 & $\mathrm{mp}$ & ly0, v0 & $\mathrm{nl}$ & 未施行 & 術後 2 年 5 力月 \\
\hline 49 & 齋藤ら & 2007 年 & 70歳/男 & 下血 & $20 \mathrm{~mm}$ & 記載なし & 0 - Isp & 内绻核 & 局所切除 & 記載なし & 記载なし & 記載なし & $\mathrm{CDV}$ & 2力月間 \\
\hline 50 & 五井 5 & 2007 年 & 86歳/女 & 血便 & $15 \times 10 \mathrm{~mm}$ & 黑色調 & 1型 & 悪性黑色腫 & 局所切除 & $\mathrm{sm}$ & ly0, v0 & $\mathrm{n} 0$ & 未施行 & 1 年 6 力月以上 \\
\hline
\end{tabular}




\begin{tabular}{|c|c|c|c|c|c|c|c|c|c|c|c|c|c|c|}
\hline 症例 & 著者 & 報告年 & 年秢/珄别 & 症状 & 腄場径 & 色調 & 肉眼形態 & 衡前診断 & 治察 & \begin{tabular}{|l|} 
深䞗度 \\
\end{tabular} & 㟲管唚獎 & リンハ節| & 補助化学療法 & 無再発生存期間 \\
\hline 51 & 河端ら & 2007年 & 70台/女 & 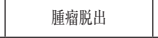 & $35 \times 33 \times 20 \mathrm{~mm}$ & 黑禓色 黒色 & 0 - Isp & 悪性黑色腫 & 直晹切断術 & sm & ly0, v0 & n0 & 誧载なし & 記载なし \\
\hline 52 & Haddow 5 & 2007年 & 58藏/女 & 下血，排便時痛 & 記载なし & 傤なし & 記载なし & 覀性黑色腄 & 直晹切断術 & 記截李し & 浬载なし & 䛉载李し & - & 診断洔遠除転移 + \\
\hline 53 & Tanaka 5 & 2008年 & 85歲/男 & 下血 & $22 \times 18 \mathrm{~mm}$ & 䘽色神 & 0 - Isp & 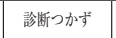 & EMR & $\mathrm{sm}$ & 語载夵し & 記载㞭し & 未施行 & 1 年10力月 \\
\hline 54 & 内海ら & 2008年 & 64歳/男 & 下紫 & $8 \mathrm{~mm}$ & 黑色 & 0 - Isp & 墨性黑色腫 & 直晹切断術 & $\mathrm{sm}$ & 記载奆し & $\mathrm{n} 0$ & 未施行 & 1 年 6 力月以上 \\
\hline 55 & 中島的 & 2008年 & 56藏/女 & 肛門部渪瘤脱出 & $17 \times 19 \times 8 \mathrm{~mm}$ & 黑色 & 0 - Ip & 墨性黑色睡 & 局所切除 & $\mathrm{sm}$ & ly0, v0 & - & DAV-feron & 3 年 6 力月以上 \\
\hline 56 & 川野乩 & 2008年 & 73歳/男 & 排便時肛門部痛 & $40 \mathrm{~mm}$ & 一部黑色 & 記载なし & 墨性黑色腫 & 未施行 & - & - & - & - & 診断洔遠滑転移 + \\
\hline 57 & 二村的 & 2009年 & 81歳/男 & 排便時出血 & $25 \times 16 \mathrm{~mm}$ & 䛌载なし & 0 -Is & 墨性黑色髀 & 局所切除 & $\mathrm{mp}$ & $\operatorname{ly}(+), V(+)$ & - & 未施行 & 3力月 \\
\hline 58 & 正村的 & 2009年: & 50歳台/男 & 排便時出血 & $10 \times 7 \mathrm{~mm}, 8 \times 6 \mathrm{~mm}$ & 暗赤色 黒色 & 0 - Isp & 悪性黑色腄 & 直晹切断術 & $\mathrm{sm}$ & lyl, vl & $\mathrm{nl}$ & DAV & 9 年以上 \\
\hline 59 & " & & 60歲台/女 & 血便 & $18 \times 10 \mathrm{~mm}$ & 黑色 & $0-\mathrm{Ip}$ & 覀性黑色腄 & 直晹切断術 & $\mathrm{sm}$ & ly2, v2 & $\mathrm{nl}$ & DAV-feron & 2 年 2 力月 \\
\hline 60 & " & & 40歲台/女 & 䏠門部黑色班 & $10 \mathrm{~mm}$ & 黑色 & 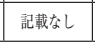 & 記载㞭L & 直晹切断術 & $\mathrm{m}$ & ly0, v0 & $\mathrm{n} 0$ & DAV-feron & 1 年 9 力月以上 \\
\hline 61 & 猪驸战 & 2009年 & 58歳/女 & 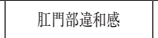 & $25 \times 17 \mathrm{~mm}$ & 黑色阔 & 0 -Isp & 悪性黑色隀 & 直腸切断術 & $\mathrm{sm}$ & ly0, v0 & n0 & DAV & 記载㞭L \\
\hline 62 & " & & 70歳/女 & 排便時出血 & $60 \times 50 \mathrm{~mm}$ & 黑色 & 1型 & 䛦断加求 & 低位前方切除 & ss & 記载なし & $\mathrm{n} 0$ & DAV & 5年9力月間 \\
\hline 63 & $"$ & & 67歲/女 & 排便時出血 & $25 \times 25 \mathrm{~mm}$ & 一部黑色 & 1型 & 悪性黑色隀 & 直晹切断術 & a & 阵戒なし & $\mathrm{nl}$ & DAC-Tam & 1年3 力月上 \\
\hline 64 & " & & 45歲/女 & 下血 & 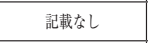 & $\begin{array}{l}\text { 黑筸色 } \\
\end{array}$ & 0 - Isp & 覀性黑色腫 & 直晹切断術 & $\mathrm{m}$ & ly0, v0 & n0 & DAC-Tam & 1 年 3 力月以上 \\
\hline 65 & 持田战 & 2009年 & 69藏/女 & 䏠門出血 & $20 \mathrm{~mm}$ & 黑色 & 0 - Isp & 悪性黑色腄 & 直腸切断術 & 記戴なL & 䛌载なし & $\mathrm{n} 0$ & DAV & 3 年 5 力月以上 \\
\hline 66 & " & & 74藏/男 & 肛門部腫瘤 & 記载なし & 黑色 & $0-\mathrm{Ip}$ & 記载なし & 局所切除 $\rightarrow$ 直晹切断術 & 記戴なし & $\operatorname{ly}(+)$ & - & 未施行 & 2力月 \\
\hline 67 & 葛西战 & 2009年 & 67歳/女 & 下血 & $45 \times 35 \mathrm{~mm}$ & 一部淡黑色摆 & 0 - Isp & 墨性黑色隀 & 直晹切断術 & 記戴李L & $\operatorname{ly}(+), v(+)$ & n0 & DAV & 8カ月 \\
\hline 68 & 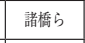 & 2010年 & 79藏/女 & 腓門部陣瘤 & $25 \mathrm{~mm}$ & 黑色神 & 0 - Isp & $\begin{array}{l}\text { 悪性黑色腫 } \\
\end{array}$ & 局所切除 $\rightarrow$ 直腸切断県 & $\mathrm{sm}$ & ly0, v0 & $\mathrm{n} 1$ & 未施行 & 1 年以上 \\
\hline 69 & 久永ら & 2010年 & 76歳/男 & 䏠門部痛 & $54 \times 45 \mathrm{~mm}$ & 一部黑色調 & 2型 & 墨性黑色畽 & 直晹切断術 & a & ly0, v0 & n2 & DAV-feron & 4カ月 \\
\hline 70 & $"$ & & 85歲/女 & 排便洔出血，眐門部神 & $43 \times 23 \mathrm{~mm}$ & 黑色 & 1型 & 悪性黑色隀 & 直晹切断術 & $\mathrm{mp}$ & ly0, v0 & $\mathrm{nl}$ & 未施行 & 8力月 \\
\hline 71 & 山田ら & 2010年 & 77歳/女 & 排便時出血 & $25 \mathrm{~mm}$ & 一部黑色 & $0-\mathrm{Ip}$ & 中～低分化腺癌 & 局所切除 $\rightarrow$ 直腸切断術 & $\mathrm{sm}$ & ly3, v0 & $\mathrm{n} 2$ & 不明 & 2力月間 \\
\hline 72 & 位夕枋 & 2010年 & 64藏/男 & 下血 & $20 \times 15 \mathrm{~mm}$ & 周囲粘膜と同調 & 0 - Isp & 悪性黑色腄 & 直腸切断術 & $\mathrm{sm}$ & $\operatorname{ly}(+), V(+)$ & $\mathrm{n} 2$ & 未施行 & 13日閏 \\
\hline 73 & 中森战 & 2010年 & 63藏/女 & 下血 & $16 \mathrm{~mm}$ & 赫蝎色, 黑色班 & $0-\mathrm{Ip}$ & 覀性黑色腄 & 直晹切断術 & ai & 浬载なし & n2 & CDDP, IFN- $\beta$ & 2力月間 \\
\hline 74 & 古本的 & 2011年 & 67歳/女 & 排便時出血 & $35 \times 25 \mathrm{~mm}$ & 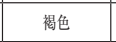 & 0 - Isp & 低分化腺癌 & 局所切除 $\rightarrow$ 直晹切断術 & sm & ly0, v1 & $\mathrm{nl}$ & 未施行 & 6力月間 \\
\hline 75 & 今川ら & 2011年 & 72藏/女 & 血便 & $10 \times 18 \mathrm{~mm}$ & 黑色 & $0-\mathrm{Ip}$ & $\begin{array}{l}\text { 悪性黑色腫 } \\
\end{array}$ & 直晹切断術 & $\mathrm{sm}$ & lyl, v1 & n2 & DAV & 6力月間 \\
\hline 76 & 中山ら & 2011年 & 67歲/女 & なん & $18 \times 10 \mathrm{~mm}$ & 黑色 & $0-\mathbb{I I} a$ & 悪性黑色睡 & 直晹切断術 & 記戴李L & ly0, v0 & n0 & DAV-feron & 1 年以上 \\
\hline 77 & 横田的 & 2011年 & 56藏/男 & 血便 & $20 \times 26 \mathrm{~mm}$ & 黑色湖 & 0 -Is & 墨性黑色睡 & 直晹切断術 & $\mathrm{m}$ & ly0, v0 & $\mathrm{n} 0$ & 未施行 & 7 年以上 \\
\hline 78 & 土橋ら & 2011年 & 56歳/女 & 排便時出血, 肍門部嶰 & $65 \times 50 \mathrm{~mm}$ & 周囲粘膜と同調 & 1型 & 低分化腺癌 & 直晹切断術 & a & 諊载奆し & $\mathrm{n}(+)$ & imatinib & 31 90日間 \\
\hline 79 & 桑田战 & 2012年 & 46藏/女 & 便潜血陽性 & $35 \times 20 \mathrm{~mm}$ & 発赤 & 2型 & 墨性黑色睡 & 直晹切断術 & $\mathrm{mp}$ & ly0, v1 & $\mathrm{n} 0$ & DAV & 12力月以上 \\
\hline 80 & 山崎ら & 2012年 & 63藏/女 & 下血 & $30 \times 17 \mathrm{~mm}, 7 \times 5 \mathrm{~mm}$ & 一部黑色 & $0-\mathrm{Ip}$ & 覀性黑色腄 & 直晹切断術 & sm & ly1, v0 & $\mathrm{nl}$ & 未施行 & 8年以上 \\
\hline 81 & 伊藏ら & 2012年 & 67藏/女 & 便潜血晹性 & $7 \mathrm{~mm}$ & 黑色 & 0 - Ip & 墨性黑色瘇 & 直晹切断術 & $\mathrm{m}$ & ly0, v0 & $\mathrm{n} 0$ & 未施行 & 1 年 6 力月以上 \\
\hline 82 & 谷凮战 & 2012年 & 61藏/女 & 便潜血踢性 & $20 \times 10 \mathrm{~mm}, 5 \times 8 \mathrm{~mm}$ & $\begin{array}{l}\text { 黑簜色 } \\
\end{array}$ & 0 - Isp & 墨性黑色腫 & 直晹切断術 & $\mathrm{sm}$ & ly0, v1 & $\mathrm{nl}$ & DAV & 10力月上上 \\
\hline 83 & 簙田ら & 2012年 & 70歲台/男 & 下血, 便の狭小化 & $40 \times 20 \mathrm{~mm}$ & 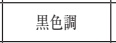 & 2型 & 悪性黑色睡 & 直晹切断術 & $\mathrm{mp}$ & ly2, v0 & $\mathrm{nl}$ & 未施行 & 6力月間 \\
\hline 84 & 得能战 & 2012年 & 66藏/男 & 便通異常，肪門痛 & $60 \times 55 \mathrm{~mm}$ & 黑色涸 & 1型 & 墨性黑色睡 & 直晹切断術 & $\mathrm{mp}$ & lyl, v1 & n2 & 未施行 & 22日閧 \\
\hline 85 & 喜多5 & 2012年 7 & 70踚台/男 & 排便時出血 & $15 \times 20 \mathrm{~mm}$ & 黑色 & 0 - Isp & 墨性黑色睡 & 直晹切断術 & $\mathrm{sm}$ & lyl, v1 & $\mathrm{nl}$ & 未施行 & 5力月上 \\
\hline 86 & 上野万 & 2012年 & 84藏/女 & 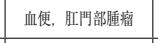 & $40 \mathrm{~mm}, 35 \mathrm{~mm}$ & 黑䄎色 & 0 - Isp, 0 - I & 悪性黑色腫 & 局所切除 & $\mathrm{sm}$ & ly1, v0 & - & 未施行 & 1年6力月間 \\
\hline 87 & 高原ら & 2012年 & 80歲台/女 & 血便 & $15 \mathrm{~mm}$ & 褐色满 & 0 - Isp & 墨性黑色畽 & EMR & $\mathrm{sm}$ & 浬载夵し & 䛉载奆し & 未施行 & 14力月上上 \\
\hline 88 & 剛崎战 & 2013年 & 74藏/男 & 排便時出血 & $15 \mathrm{~mm}$ & 黑蝎色 & 0 - Isp & 悪性黑色隀 & 直晹切断術 & $\mathrm{sm}$ & + & $\mathrm{nl}$ & 未施行 & 記载㞭し \\
\hline 89 & 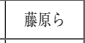 & 2013年 & 54藏/男 & 下血，排便時䏣門部蒋 & $65 \times 63 \mathrm{~mm}$ & 黑色洞 & 2型 & $\begin{array}{l}\text { 悪性黑色腫 } \\
\end{array}$ & 直晹切断術 & a & 記载なし & $\mathrm{n} 0$ & DAC-Tam & 6力月間 \\
\hline 90 & 别府战 & 2014年 & 74歲/女 & 腹部擞渾感 & 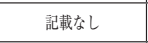 & 一部黑色 & 0 - Isp & 悪性黑色睡 & 未施行 & - & - & - & 未施行 & 記载李し \\
\hline 91 & 中尾战 & 2014年 & 82藏/男 & 下血 & $16 \times 8 \times 15 \mathrm{~mm}$ & 黑色 & $0-\mathrm{Ip}$ & 炎症性ポリープ & 直晹切断術 & ai & 誂截なし & n0 & 未施行 & 5 力月以上 \\
\hline 92 & 呉林战 & 2015年 & 80藏/女 & 下血 & $100 \times 85 \mathrm{~mm}$ & 一部黑色 & 5型 & 悪性黑色睡 & 直晹切断術 & a & 誡载奆し & $\mathrm{nl}$ & なし & 䛦断封透谝転移 + \\
\hline 93 & 橨井5 & 2015年 & 52藏/女 & 肍門出血 & $37 \times 27 \times 20 \mathrm{~mm}$ & 黑色 & 0 - Isp & 記截なし & 局所切除 & $\mathrm{sm}$ & 轪截なし & - & DAV & 5年6力月 \\
\hline 94 & 間島的 & 2015年 & 83歳/女 & 血便 & $9 \mathrm{~mm}$ & 举䃾色 & 0 - Isp & 悪性黑色腫 & 直腸切断術 & $\mathrm{m}$ & $\mathrm{Iy} 0, \mathrm{v} 0$ & $\mathrm{n} 0$ & 未施行 & 2 年 6 力月以上 \\
\hline 95 & 田旗ら & 2015年 & 84藏/女 & 下血 & $40 \times 20 \mathrm{~mm}$ & 一部黑色 & $0-I p$ & 悪性黑色隀 & 局所切除 & $\mathrm{sm}$ & lyl, vl & - & IFN & 6力月間 \\
\hline 96 & 藤原战 & 2015年 & 62藏/男 & なし & $20 \mathrm{~mm}$ & 黑色 & 1型 & 悪性黑色睡 & 未施行 & 記戴なし & lyl, v0 & n2 & なし & 䛦断封薏滑転移 + \\
\hline 97 & 北川5 & 2016年 & 90藏/女 & 下血 & $20 \times 15 \mathrm{~mm}$ & 薄い黑色+赩色 & 0 - Ip & 悪性黑色睡 & 局所切除 & $\mathrm{sm}$ & ly0, v0 & - & 未施行 & 27力月以上 \\
\hline 98 & 片山ら & 2016年 & 76藏/男 & なし & $6 \times 4 \mathrm{~mm}$ & 黑色 & 0 -II a & 墨性黑色睡 & 直晹切断術 & $\mathrm{mp}$ & ly0, v0 & $\mathrm{n} 0$ & 未施行 & 12力月以上 \\
\hline 99 & 小林ら & 2016年 & 85歲/女 & 耻門部陣脤 & $30 \times 15 \mathrm{~mm}$ & 黑蝎色 & 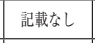 & 墨性黑色隀 & 直晹切断術 & a & $\operatorname{ly}(+), V(+)$ & $\mathrm{nl}$ & 未施行 & 5力月 \\
\hline $100 \mathrm{~A}$ & $M$ atsuda 5 & 2016年 & 61藏/女 & 下血 & 記载㞭し & 黑色 & 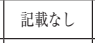 & 悪性黑色睡 & 直肠切断術 & $\mathrm{mp}$ & 轪截なし & n2 & DTIC & 1年間 \\
\hline 101 & 自䀢例 & & 68歳/女 & 画像黑常 & $26 \times 23 \mathrm{~mm}$ & 黑色 & 0 - Isp & 墨性黑色腫 & 直腸切断術 & $\mathrm{sm}$ & lyl, v0 & n0 & 未施行 & 15力月以上 \\
\hline
\end{tabular}


ローナル抗体である nivolumabやヒト型抗ヒト cytotoxic-T-lymphocyte-associated antigen 4 (CTLA-4) モノクローナル抗体である ipilimumab, v-Raf murine sarcoma viral oncogene homolog B1 (BRAF) 阻害剂である vemurafenibがDTICを大きく上回る奏

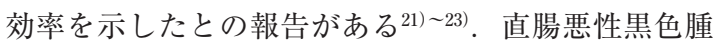
に対する使用例の報告はないが直腸悪性黒色腫に対し ても有用な可能性があると考えられる。

本症例では悪性リンパ腫に対して R-MPV 療法が施 行され，悪性黒色腫にも感受性を示したためか腫瘍の 縮小効果を認めた．医学中央雑誌で「直腸悪性黒色腫」 「術前化学療法」をキーワードとして検索（会議録を 除く）したが, 直腸悪性黒色腫に対し術前化学療法を 施行した報告例は認められなかった. PubMedで $\lceil$ anorectal malignant melanoma」「neoadjuvantchemotherapy」をキーワードに検索（会議録を除く） したところ 1 例の報告例を認めた ${ }^{24)}$ 。直腸低分化型腺 癌の診断で術前化学放射線療法として capesitabine 単 剂投与および放射線療法を施行した 1 例であった，術 前化学放射線療法により腫瘤の縮小効果を認め括約筋 間切除術が可能となったと報告されている. 自験例で は直腸病変に対して術前放射線療法は施行されておら ず，また化学療法のレジメンが異なっているため比較 検討は困難であるが，直腸悪性黒色腫に対しても術前 治療が有効な可能性があると考えられる.

\section{結語}

悪性リンパ腫の精查を機に発見された直腸悪性黒色 腫の 1 例を経験した。直腸悪性黒色腫は症例数が少な く、コンセンサスが得られた治療法が確立されていな いのが現状である，治療成績向上のためには，今後更 なる症例の蓄積が必要と考えられる.

利益相反：なし

\section{文献}

1) Nam $S$, Kim CW, Baek SJ, et al : The clinical features and optimal treatment of anorectal malignant melanoma. Ann Surg Treat Res 2014; $87: 113-117$

2) Chen H, Cai Y, Liu Y, et al : Incidence, Surgical Treatment, and Prognosis of Anorectal Melanoma From 1973 to 2011. Medicine (Baltimore) 2016 ; 95 : e2770

3）中村和正, 大曲淳一, 國武直信他: 非ホジキンリン パ腫における重複癌症例の検討。癌の臨 2013；
$45: 407-413$

4）岡本秀一, 志野佳秀, 榎本浩士他：直腸肛門原発の 無色素性悪性黑色腫の 1 例。日臨外会誌 2004； $65: 1012-1016$

5）柴田佳久：無色素性から色素性へと色調変化をき たした直腸肛門部悪性黒色腫の 1 例. 日本大腸肛 門病会誌 $2004 ; 57: 389-395$

6）坂本 力, 井本勝治, 村上陽子他：【直腸肛門部 病変の鑑別診断】直腸, 肛門の CT ・ MRIの診断 法. 胃と腸 $2003 ； 38 ： 1263-1273$

7）原 睛久, 浅野道雄, 浅井秀司他：長期生存した直 腸肛門部悪性黑色腫の 1 例. 日消外会誌 1992 ； $25: 2046-2049$

8) Yeh JJ, Shia J, Hwu WJ, et al : The role of abdominoperineal resection as surgical therapy for anorectal melanoma. Ann Surg 2006 ; 244 : 1012 $-1017$

9) Malik A, Hull TL, Milson J : Long-term survivor of anorectal melanoma. Dis Colon Rectum 2002 ; $45: 1412-1417$

10）中島 亨, 小関萬里, 富永晴海他: 原発巣局所切 除と免疫化学療法により 3 年半の無再発生存を認 めている直腸肛門部悪性黑色腫の 1 例. 日消外会 誌 $2008 ; 41 ： 1746-1751$

11）諸橋 一, 矢越雄太, 山田恭吾他: 直腸肛門部悪 性黒色腫の 1 例。治療 $2010 ; 92: 2068-2071$

12）佐々木愼, 小島徹, 秀村昆生他: DTIC/ ACNU/VCR 療法によりCRが得られた直腸肛門 部悪性黒色腫の 1 例. 癌と化療 $2010 ； 37 ： 1999$ $-2002$

13）今川敦夫, 和田範子, 豊田 翔他: 早期に再発し た粘膜下浸潤直腸肛門部悪性黑色腫の 1 例. 日外 科系連会誌 $2011 ； 36 ： 971-975$

14) Arakawa $K$, Kiyomatsu $T$, Ishihara $S$, et al : A case of anorectal malignant melanoma with mucosal skipped lesion. Int J Surg Case Rep 2016 ; $24: 206-210$

15）長谷川小百合, 貞廣莊太郎, 鈴木俊之 : 多発病巣 を有し長期生存した直腸悪性黒色腫の 1 例. 日本 大腸肛門病会誌 $2005 ; 58: 255-259$

16）秦 史壮, 八十島孝博, 西森英史他：上皮内 pagetoid spreadを伴った直腸肛門部悪性黒色腫の 1 例. 日本大腸肛門病会誌 $2003 ; 56: 279-283$

17）川野紀子, 田代充生, 田口雅史他：IFN- $\beta$ 併用 
多剂化学療法（DAC-Tam療法）が奏功した直腸 肛門部悪性黒色腫の 1 例。 日消誌 2008；105： $1627-1633$

18）山田正樹, 小野誠吾, 石山 隼他：術後の早期再 発に対する化学療法が奏功している直腸肛門部悪 性黒色腫の 1 例。 日外科系連会誌 $2010 ； 35: 78$ $-84$

19）藤原一郎, 高垣敬一, 西尾康平他: Weekly Paclitaxel 療法を行った直腸肛門部悪性黒色腫の 1 例. 日本大腸肚門病会誌 $2013 ; 66: 364-368$

20）吳林秀崇, 高嶋吉浩, 宗本義則他：CP療法にて $\mathrm{PR}$ が得られた直腸肛門部悪性黒色腫の 1 例。 日 本大腸肛門病会誌 $2015 ; 68: 46-50$
21）清原祥夫：新たに開発された抗体治療 悪性黒色 腫. がん分子標的治療 $2015 ; 13: 212-216$

22）浦田 透, 山崎直也：遺伝子解析に基づくがん治 療 悪性黒色腫. がん分子標的治療 2016；14： $30-35$

23）宇原 久：悪性黒色腫 分子標的薬治療. Pharm Med $2015 ; 33: 15-19$

24) Su M, Zhu L, Luo W, et al : Primary anorectal malignant melanoma treated with neoadjuvantchemoradiotherapy and sphincter-sparing surgery : A case report. Oncol Lett $2014 ; 7$ : $1605-1607$

\title{
A CASE OF ANORECTAL MALIGNANT MELANOMA COMPLICATED BY MALIGNANT LYMPHOMA
}

\author{
Hiroki KANNO, Yoshiyuki NAKANO, Hiroshi KIKUCHI, \\ Hiroshi OKAMOTO, Kai MAIDA and Norinobu OGASAWARA \\ Department of Surgery, Sendai City Hospital
}

Anorectal malignant melanoma is a rarely encountered disease that carries a poor prognosis. We report a case of anorectal malignant melanoma complicated by malignant lymphoma.

A 68-year-old woman presented to us complaining of reduced visual acuity. She was diagnosed as having sarcoid, uveitis and initiated on oral steroid treatment. However, as no symptomatic improvement was observed biopsy of the vitreous body was performed, which revealed findings consistent with malignant lymphoma. FDG/PET showed a high accumulation of FDG in the left temporal lobe, hepatic portal lesion, paraaortic lesion and rectum. Colonoscopy showed a pedunculated black-colored polyp in the rectum, and biopsy revealed anorectal malignant melanoma. We selected neoadjuvant chemoradiotherapy with the R-MPV regimen (rituximab, methotrexate, procarbazine, vincristine) for the malignant lymphoma, because the tumor rapidly caused disturbance of consciousness. This resulted in complete disappearance of the symptoms and complete reversal of the FDG accumulations on FDG/PET, except in the rectum. Anorectal malignant melanoma is also a life-threatening disease, therefore, we performed laparoscopic abdominoperineal resection after 5 courses of the R-MPV regimen with concurrent radiation.

Until now, 15 months since the surgery, the patient has shown no evidence of recurrence of the malignant melanoma.

Key words : anorectal melanoma, malignant lymphoma 